\title{
Physician challenges in medical error disclosure - a case study in undergraduate medical student education
}

\author{
Sangita Sukumaran \\ ${ }^{1}$ Professor and Head, Department of Pharmacology, Terna Medical College, Navi Mumbai and Secretary, \\ UNESCO Bioethics Unit, Terna Medical College, Navi Mumbai
}

\begin{abstract}
Background: Medical error is a mistake committed by health professionals which results in harm to the patient. Medical errors can occur due to wrong diagnosis, error in administration of drugs, error in performance of surgical procedures, error in the use of equipment or misinterpretation of laboratory findings. When medical errors occur, the most common dilemma faced by doctors is whether to disclose the error to the patient. Physicians often conceal the error due to fear of negative consequences. If medical error disclosures are handled well - patient trust in physician could increase, can be used to improve processes (enhance patient safety) and prevent lawsuit on the hospital.

Methodology: Undergarduate medical students were taught a step-wise communication process to handle disclosure of medical errors after watching role play videos depicting disclosure conversations. The role play videos depicted the wrong way and the right way of disclosure conversation. A survey was taken to assess the attitude and perception of the students after teaching about communication process. Students answered questions related to three case scenarios. For each question, three response scripts represented increasing amounts of information (no disclosure, partial disclosure, full disclosure) was taken. Principles of bioethics that are violated due to non-disclosure of medical errors were discussed.

Results: About $98 \%$ of students disclosed medical errors to the patients (partial or full disclosure).It was challenging to make a disclosure conversation after an error occurred. Students voiced the need for teaching communication skills for disclosure of medical errors in the medical curriculum.

Conclusions: While disclosure of medical error was felt important, in view of the principles of beneficence, non-maleficence and patient's autonomy, it was difficult to do so. Complete medical error disclosure should be managed as a group (health care team) process.
\end{abstract}

Key words: Medical errors, disclosure, doctor-patient relationship, bioethics principles, patient safety

\section{Introduction}

Medical care can be double-edged sword. While doctors can save lives, they can also end up harming patients. In 1999, the Institute of Medicine published a report " To Err is Human: 
Building a Safer Health system that estimated that as many as 98,000 patients in the United States die each year from preventable medical errors [1-2].

Making a mistake or causing an adverse outcome is perhaps the most devastating experience a clinician can have. Medical error is a mistake committed by health professionals which results in harm to the patient [3]. Medical errors can occur due to wrong diagnosis, error in administration of drugs, error in performance of surgical procedures, error in the use of equipment or misinterpretation of laboratory findings. When medical error occurs the most common dilemma faced by doctors is whether or not to disclose the error to the patient. Physicians often conceal the error due to fear of negative consequences. ${ }^{4}$ If medical error disclosures are handled well patient trust in physician could increase, can be used to improve processes (enhance patient safety) and prevent lawsuit on the hospital.

The doctor-patient relationship is fiduciary and is built on trust and truth telling. However as healthcare professionals one need to acknowledge that humans can commit errors and anticipate that errors can happen. A physician who has committed a medical error often faces an ethical dilemma as to how to disclose his/her mistake or whether to disclose or not his mistake [5]. The challenge of medical error disclosure is how to communicate the mistake to the patients family in a transparent way [6].

Healthcare professionals are ethically obligated to disclose information, to ensure understanding, and to allow for adequate decision making [7-8]. Disclosure of error to the patient will enhance the trust in physician and prevent law suit on to the hospital. Along with this, disclosure to the hospital management will help to improve processes and reduce errors in the future.

The undergraduate medical curriculum in India seldom teaches the process of medical error disclosure during their training. To ensure patient safety and patient care, medical students should be taught the communication process of medical error disclosure to patients and their families. Frequent trainings will ensure less medication errors in clinical practice and will help the medical student to be prepared when handling medical errors in real life situation. It is important to inculcate positive disclosure attitudes early in the medical education process [9].

This study was undertaken in second year undergraduate medical students with the following objectives.

1. Create awareness about reporting medical errors

2. Understand the principles of bioethics violated in Non disclosure of Medical Errors

3. Teach undergraduate medical students communication process of handling medical error disclosure to patients and relatives.

\section{METHODOLOGY}

Seventy nine II MBBS students participated in the study. Participation in the study was voluntary. The concept and ethical dilemmas faced during medical error disclosure was briefed to the students. Trainees learn disclosure skills through direct observation of supervising physicians [10].

Students watched role play videos of two scenarios each of which centred around a medical error and each of which showed a disclosure conversation with the patient's family [11].First the wrong way of disclosure was shown followed by a second video showing the correct way of disclosure. A senior physician of the team led the disclosure conversation.

Students were told to think what has gone wrong in the conversation and what could have been done better. The video showed an elderly patient admitted to an hospital who required a central line to be put in the neck. However, the intern who did the procedure, nicked the apex of the lung, giving a pneumothorax to the patient and further complications. 
The role play video was followed by a discussion to highlight the key points in medical error disclosure. A step wise disclosure process was discussed.

\section{Step wise Disclosure Conversation Process [11-12]}

The most important principle in medical error disclosure is to remember that it is a disclosure process and not an event.

The first step after a medical error has occurred is to prepare ourselves to disclose the error.

\section{Common emotional responses}

There will be common emotional responses of fear, guilt, shame, sense of failure and isolation. Physicians need support in working through their own emotions and responses. It is important to get a personal handle over our emotions so that we don't walk in the room with the emotions and distract from our most important mission i.e. to be there for the patient. We are taught to be healers and there is not enough training on human factors. We are human and that we can make errors. It is important to anticipate the errors and devise a system to minimise the errors. We should acknowledge our feelings and if we don't it may negatively impact our relation with the patient. Feeling of fear, of loss of reputation, feeling alone which may be exacerbated by our colleagues' reaction, judging each other when things have gone wrong can come in the way of our explicit expression of the medical error to the patient. Medical error disclosure is a team effort. The conversation should be led by the senior most physician. Expression of empathy should come very naturally to the physician.

\section{Preparing for the conversation}

Second important step is to set up the meeting with the patients family so that it is private, not distracted and totally focussed. Choose a private room for the disclosure conversation. Take along people with whom the patient has developed a relationship during his treatment. It could be the nurse, pharmacist or intern. It is important to address the family as a team.

Communicate the facts clearly. Sit down in front of the family and make eye contact. Be clear as to what happened. Most important challenge is to translate the facts into non-jargon and not rushing through an explanation. Physician should speak in a clear language which is understandable for the patient and his family.

\section{Do not speculate}

One may have only part of the information about what happened. It is important to avoid speculation. It is like saying I think you have A but you may also have B or C. This should be avoided as it creates more confusion and is destructive for the doctor-patient relationship. One has to be mindful about creating the sense of trust. If you don't know the answer to the questions, say you don't know and say you will get back.

\section{Allow patient to express feelings.}

There is a natural tendency to get out of the situation as soon as possible. It may happen one may rush the conversation. It is important to allow the patient to express his/her feelings. We always hope that the patient would say its ok and that they forgive the doctor. It is not the patient's job to forgive the doctor. But if they forgive, it should be considered a gift. It is important for patient to ask questions. If we wait for questions, patient may not ask them as patient may be feeling intimidated. Therefore it is important to ask if they have any questions. We cannot control patient's reaction. As doctors we have to control our emotions.

\section{Express Empathy and Apology}

It is important to express empathy and say "I am sorry that this happened". Apologies may help deter legal action and promote more effective settlements. Physicians need to respond to medical errors with an apology. However, apologies should be used with caution. Apologies that accept responsibility are more effective than similar expressions that simply express sympathy [13]. 


\section{Learning from the Medical Error}

As an institution it is important to learn from medical errors that have happened. It is important to have team reflections about what was learnt from the disclosure. Did we do the disclosure conversation the right way and how it can be improved.

\section{Physician support}

Disclosure coaching and peer support are useful to help prepare for disclosure conversation so that we learn to present in a compassionate way to patient about our accountability, improving patient safety and quality in future.

\section{Avoid Common Pitfalls}

There are some pitfalls that we fall into as clinicians. It is important that we do not over blame ourselves or blame others for the medical error that happened. It is very natural for us to do this when facing our own fallibility. It's a difficult moment when instead of making patient feel better we make them feel worse. When we blame ourselves excessively it is like asking for forgiveness from the patient's family unconsiocusly. It is important not to blame ourselves unless we know for sure we are to be blamed. Another problem is to avoid using jargons and lacking expression of empathy.

The goal of medical error disclosure conversation is to have the discussion in a compassionate and transparent way regarding what happened to the patient. It is important recognizing we have emotions that will make us vulnerable to be not expressing that compassion in a way that the patients can feel. Identifying our own emotions and not walking into the room with those emotions requires preparation. Being very explicit about being empathic in our language, posture and behaviour, stating facts in a clear way that does not allow jargon is important. Allowing patient to express his emotions, welcoming questions from patients, not overblaming, expressing empathy, apologising clearly and making sure that this is a process and that you are available for further questions and as an institution you have learnt from the error is very important. You should get back to patient when you have more information and make sure you follow that promise.

To test the attitude towards medical error disclosure students answered a survey questionnaire on three case scenarios (Table 1) after watching the video and following the discussion.

The Survey Questionnaire focussed on four questions mainly

1. How likely would you be to disclose this error to the patient?

2. What would you most likely say about what happened?

3. What most closely resembles what you would say about the cause of the error?

4. What would you most likely say regarding an apology?

For each question, three response scripts represented increasing amounts of information (no disclosure, partial disclosure, full disclosure). The text of these responses has been published previously [14].

\section{RESULTS}

The results of the survey are in the table below (Table 2)

\section{Disclosure content}

Respondents varied widely in the information they would disclose to patients. Overall, $79 \%$ of students chose statements explicitly stating that an error had occurred, whereas $19 \%$ mentioned the adverse event but not the error (Table 2). When asked how they would describe the cause of the error, $36 \%$ chose a specific description of exactly what the error was, $56 \%$ offered non- specific information, and $8 \%$ said they would not volunteer any explanation unless asked. 
Table 1 - The Case Scenarios

\begin{tabular}{|c|c|}
\hline Case Scenario & Description \\
\hline Insulin overdose & $\begin{array}{l}\text { You have admitted a diabetic patient to the hospital for a } \\
\text { COPD exacerbation. You handwrite an order for the patient } \\
\text { to receive "10 U" of insulin. The "U" in your order looks like } \\
\text { a } 0 \text {. The following morning, the patient is given } 100 \mathrm{U} \text { of } \\
\text { insulin, } 10 \text { times the patient's normal dose, and is later found } \\
\text { unresponsive, with a serum glucose level of } 35 \mathrm{mg} / \mathrm{dL} \text { ( } 1.94 \\
\text { mmol/L). The patient is resuscitated and transferred to the } \\
\text { intensive care unit. You expect the patient to make a full } \\
\text { recovery. }\end{array}$ \\
\hline Hyperkalemia & $\begin{array}{l}\text { You administer a new medicine with a common adverse } \\
\text { effect of increasing the potassium level to an outpatient with } \\
\text { hypertension. The patient's baseline potassium level is normal } \\
\text { ( } 4.0 \mathrm{mEq} / \mathrm{L}) \text {. You order a repeat blood test to measure } \\
\text { potassium level, to be drawn the next week, but forget to } \\
\text { check the laboratory results. Two weeks after the patient } \\
\text { begins taking this new medicine, the patient starts feeling } \\
\text { palpitations and goes to the emergency department. In the } \\
\text { emergency department, the patient experiences an episode of } \\
\text { ventricular tachycardia, requiring cardioversion. The patient's } \\
\text { potassium level at this event is } 7.5 \mathrm{mEq} / \mathrm{L} \text {. The patient is } \\
\text { hospitalized for } 4 \text { days, and makes a full recovery. The patient } \\
\text { returns to your office for a follow-up visit. On reviewing the } \\
\text { patient's chart, you see the overlooked laboratory results, } \\
\text { which showed the patient's potassium level had increased } \\
\text { substantially from } 4.0 \text { to } 5.6 \mathrm{mEq} / \mathrm{L} \text {. Had you seen this } \\
\text { elevated potassium level earlier, you would have discontinued } \\
\text { the new medicine and treated the hyperkalemia, likely } \\
\text { avoiding the life-threatening arrhythmia. }\end{array}$ \\
\hline Retained Sponge & $\begin{array}{l}\text { You are seeing a patient } 3 \text { weeks after elective splenectomy } \\
\text { for ITP. The splenectomy was technically challenging because } \\
\text { of the patient's obesity, but seemed uncomplicated. At this } \\
\text { follow-up visit, the patient complains of vague persistent LUQ } \\
\text { pain. You send the patient for an abdominal x-ray film, which } \\
\text { shows a foreign body consistent with a retained surgical } \\
\text { sponge in the patient's LUQ. You remember that the sponge } \\
\text { count was correct at the end of the procedure. However, you } \\
\text { also remember that you packed off a small bleeding vessel } \\
\text { near the stomach with a sponge, and do not recall removing } \\
\text { this sponge. When you review the postoperative records, you } \\
\text { observe that a math error was responsible for a falsely correct } \\
\text { sponge count. You believe a subsequent operation to remove } \\
\text { the retained sponge is indicated, and expect the patient will } \\
\text { make a full recovery. }\end{array}$ \\
\hline
\end{tabular}


RESULTS

\begin{tabular}{|c|c|c|c|}
\hline Type of disclosure & Insulin Overdose & Hyperkalemia & Retained Sponge \\
\hline No of participants & $\mathrm{N}=79(\%)$ & $\mathrm{N}=79(\%)$ & $\mathrm{N}=79(\%)$ \\
\hline & \multicolumn{3}{|c|}{ How likely would you be to disclose this error to the patient? } \\
\hline $\begin{array}{l}\text { No disclosure } \\
\text { (no reference to } \\
\text { adverse event or } \\
\text { error) }\end{array}$ & $\begin{array}{l}\text { I would definitely not } \\
\text { disclose this error } \\
0(0 \%)\end{array}$ & $\begin{array}{l}\text { I would definitely not } \\
\text { disclose this error } \\
2(3 \%)\end{array}$ & $\begin{array}{l}\text { I would definitely not } \\
\text { disclose this error } \\
3(4 \%)\end{array}$ \\
\hline $\begin{array}{l}\text { Partial Disclosure } \\
\text { (mentioned adverse } \\
\text { event but no error) }\end{array}$ & $\begin{array}{l}\text { I would disclose this } \\
\text { error only if asked by } \\
\text { the patient } \\
17(22 \%)\end{array}$ & $\begin{array}{l}\text { I would disclose this } \\
\text { error only if asked by } \\
\text { the patient } \\
17(22 \%)\end{array}$ & $\begin{array}{l}\text { I would disclose this } \\
\text { error only if asked by } \\
\text { the patient } \\
11(14 \%)\end{array}$ \\
\hline \multirow[t]{2}{*}{$\begin{array}{l}\text { Full Disclosure } \\
\text { (explicit statement } \\
\text { that error occurred) }\end{array}$} & $\begin{array}{l}\text { I would definitely } \\
\text { disclose this error } \\
62(78 \%)\end{array}$ & $\begin{array}{l}\text { I would definitely } \\
\text { disclose this error } \\
60(77 \%)\end{array}$ & $\begin{array}{l}\text { I would definitely } \\
\text { disclose this error } \\
65(82 \%)\end{array}$ \\
\hline & \multicolumn{3}{|c|}{ What would you most likely say about what happened } \\
\hline $\begin{array}{l}\text { No disclosure } \\
\text { (no reference to } \\
\text { adverse event or } \\
\text { error) }\end{array}$ & $\begin{array}{l}\text { Your blood sugar } \\
\text { went too low and you } \\
\text { passed out. } \\
3(4 \%)\end{array}$ & $\begin{array}{l}\text { Your potassium level } \\
\text { got too high, which } \\
\text { led to a dangerous } \\
\text { heart rhythm. } \\
5(6 \%)\end{array}$ & $\begin{array}{l}\text { The x-ray showed an } \\
\text { abnormality that } \\
\text { could be serious. } \\
\text { Another operation } \\
\text { will be required to } \\
\text { investigate and } \\
\text { correct this problem. } \\
4(5 \%)\end{array}$ \\
\hline $\begin{array}{l}\text { Partial Disclosure } \\
\text { (mention adverse } \\
\text { event but not error) }\end{array}$ & $\begin{array}{l}\text { Your blood sugar } \\
\text { went too low because } \\
\text { you received more } \\
\text { insulin than you } \\
\text { needed. } \\
9(11 \%)\end{array}$ & $\begin{array}{l}\text { The new medicine } \\
\text { we started caused } \\
\text { your potassium level } \\
\text { to become too high, } \\
\text { which led to a } \\
\text { dangerous heart } \\
\text { rhythm. } \\
23(29 \%)\end{array}$ & $\begin{array}{l}\text { During the surgery, a } \\
\text { sponge was } \\
\text { inadvertently left in } \\
\text { your abdomen. } \\
\text { Another operation } \\
\text { will be required to } \\
\text { remove the sponge. } \\
11(14 \%)\end{array}$ \\
\hline $\begin{array}{l}\text { Full Disclosure } \\
\text { (explicit statement } \\
\text { that error occurred) }\end{array}$ & $\begin{array}{l}\text { Your blood sugar } \\
\text { went too low because } \\
\text { an error happened } \\
\text { and you received too } \\
\text { much insulin. } \\
67(85 \%)\end{array}$ & $\begin{array}{l}\text { You had a dangerous } \\
\text { heart rhythm because } \\
\text { an error happened } \\
\text { and we did not notice } \\
\text { that the new } \\
\text { medicine had caused } \\
\text { your potassium to } \\
\text { become too high. } \\
51(65 \%)\end{array}$ & $\begin{array}{l}\text { We will have to do } \\
\text { another operation } \\
\text { because an error } \\
\text { happened and a } \\
\text { sponge was left in } \\
\text { your abdomen. } \\
64(81 \%)\end{array}$ \\
\hline
\end{tabular}




\begin{tabular}{|c|c|c|c|}
\hline & \multicolumn{3}{|c|}{$\begin{array}{l}\text { What most closely resembles what you would say about the cause of } \\
\text { the error? }\end{array}$} \\
\hline $\begin{array}{l}\text { No Disclosure } \\
\text { (no information } \\
\text { volunteered about } \\
\text { cause } \\
\text { of error) } \\
\end{array}$ & $\begin{array}{l}\text { I would not volunteer } \\
\text { a cause of the error } \\
\text { unless the patient } \\
\text { asked me. } \\
4(5 \%)\end{array}$ & $\begin{array}{l}\text { I would not volunteer } \\
\text { a cause of the error } \\
\text { unless the patient } \\
\text { asked me. } \\
10(13 \%)\end{array}$ & $\begin{array}{l}\text { I would not volunteer } \\
\text { a cause of the error } \\
\text { unless the patient } \\
\text { asked me. } \\
5(6 \%)\end{array}$ \\
\hline $\begin{array}{l}\text { Partial Disclosure } \\
\text { (non-specific } \\
\text { information hinting } \\
\text { at cause) }\end{array}$ & $\begin{array}{l}\text { This occurred } \\
\text { because of a } \\
\text { miscommunication } \\
\text { about your insulin } \\
\text { order. } \\
43(54 \%)\end{array}$ & $\begin{array}{l}\text { This occurred } \\
\text { because of a mix-up } \\
\text { regarding your } \\
\text { laboratory results. } \\
55(70 \%)\end{array}$ & $\begin{array}{l}\text { This occurred } \\
\text { because of a problem } \\
\text { with the sponge } \\
\text { count. } \\
35(44 \%)\end{array}$ \\
\hline \multirow[t]{2}{*}{$\begin{array}{l}\text { Full Disclosure } \\
\text { (detailed description } \\
\text { of why error } \\
\text { happened) }\end{array}$} & $\begin{array}{l}\text { My handwriting is } \\
\text { sometimes difficult to } \\
\text { read. I wrote your } \\
\text { order for " } 10 \text { U" of } \\
\text { insulin and the "U" } \\
\text { looked like a "0." } \\
\text { Therefore, you } \\
\text { received } 100 \text { units of } \\
\text { insulin instead of } 10 . \\
\text { This also slipped by } \\
\text { our nurse and } \\
\text { pharmacist. } \\
32(41 \%)\end{array}$ & $\begin{array}{l}\text { I did not remember } \\
\text { to check the results of } \\
\text { the laboratory tests } \\
\text { you had drawn the } \\
\text { week after you } \\
\text { started the new } \\
\text { medicine. The } \\
\text { laboratory and the } \\
\text { nurse also did not } \\
\text { notify me about the } \\
\text { high potassium. } \\
14(18 \%)\end{array}$ & $\begin{array}{l}\text { This occurred } \\
\text { because I forgot that I } \\
\text { had put a sponge } \\
\text { deep in your } \\
\text { abdomen to control } \\
\text { some bleeding. Also, } \\
\text { the sponge count was } \\
\text { done incorrectly, so I } \\
\text { was unaware that not } \\
\text { all the sponges had } \\
\text { been removed. } \\
39(49 \%)\end{array}$ \\
\hline & \multicolumn{3}{|c|}{ What would you most likely say regarding an apology? } \\
\hline $\begin{array}{l}\text { No Disclosure } \\
\text { (No apology) }\end{array}$ & $\begin{array}{l}\text { I would not volunteer } \\
\text { that I was sorry or } \\
\text { apologize. } \\
1(1 \%)\end{array}$ & $\begin{array}{l}\text { I would not volunteer } \\
\text { that I was sorry or } \\
\text { apologize. } \\
5(6 \%)\end{array}$ & $\begin{array}{l}\text { I would not volunteer } \\
\text { that I was sorry or } \\
\text { apologize. } \\
3(4 \%)\end{array}$ \\
\hline $\begin{array}{l}\text { Partial Disclosure } \\
\text { (expression } \\
\text { of regret) }\end{array}$ & $\begin{array}{l}\text { I am sorry about } \\
\text { what happened. } \\
35(44 \%)\end{array}$ & $\begin{array}{l}\text { I am sorry about } \\
\text { what happened. } \\
27(34 \%)\end{array}$ & $\begin{array}{l}\text { I am sorry about } \\
\text { what happened. } \\
28(35 \%)\end{array}$ \\
\hline $\begin{array}{l}\text { Full Disclosure } \\
\text { (explicit apology) }\end{array}$ & $\begin{array}{l}\text { I am so sorry that } \\
\text { you were harmed by } \\
\text { this error. } \\
43(54 \%)\end{array}$ & $\begin{array}{l}\text { I am so sorry that } \\
\text { you were harmed by } \\
\text { this error. } \\
47(60 \%)\end{array}$ & $\begin{array}{l}\text { I am so sorry that } \\
\text { you were harmed by } \\
\text { this error. } \\
48(61 \%)\end{array}$ \\
\hline
\end{tabular}

Among the 79 students who indicated they would definitely disclose the error, many limited disclosure content (79\% described the error as an adverse event and $21 \%$ made partial or no disclosure of the cause of the error). Nearly all students (96\%) would offer some form of apology, but students were split between conveying a general expression of regret (38\%) and making an explicit apology (58\%). 


\section{Limitations of the survey}

The study revealed that in hypothetical situations, $98 \%$ of students were willing to disclose medical errors, however in real life situations it may not be so. Although physicians believe that medical errors should be disclosed to patients and their families, they often hesitate to do so. The survey was restricted only to medical students.

\section{Principles of Bioethics and Non disclosure of medical errors [15-16]}

The principles of bioethics that are violated in non-disclosure of medical errors was discussed with students. By not disclosing a medical error, the doctor conspicuously places his own interests above that of the patient to the detriment of the patient, thereby violating a patientcentered ethical principle.

\section{DISCUSSION}

Disclosing medical errors to patients have ethical rationales such as informed consent, truthtelling, justice and fairness [15]. If a doctor conceals a medical error, he's violating the principles of bioethics. According to the principle of autonomy it is patient's right to have full information about the treatment and any error if occurred. Physicians tend to hide the error when patient do not ask about it, and this is referred as deceptive approach .Principle of autonomy supports truth telling therefore, disclosure of fact with the patient is highly justified. Deceiving patients interferes with the doctrine of informed consent since patients may not understand the reason or need for additional interventions or a longer hospital stay that becomes necessary as a means of rectifying an undisclosed error. It is therefore important to disclose errors in order to respect autonomy and facilitate the giving of informed consent.

The principle of beneficence in medical practice refers to avoid and prevent error by doing well. Failing to disclose a medical error that has occurred to a patient and letting the patient assume that what he or she is going through is due to the disease is unkind and violates the principle of beneficence. On the other hand, the patient's knowledge and understanding that a mistake or error has occurred may relieve anxiety about slow recovery or complications and will certainly bring benefits.

The principle of non-maleficence emphasizes that one should not cause harm to oneself and others. When patients come to a health care system to seek care, they trust the system and health care providers. They expect competency and believe that physician will provide the best treatment in accordance with the principle of beneficence. As a moral obligation, the principle of beneficence guides us to remove condition that will harm others, and prevent harm from occurring to others .Although an error may harm a patient, failure to disclose the error to the patient makes the situation worse. A patient may worry needlessly about his or her prolonged stay or worsening condition thinking it is a result of the underlying disease. Knowing that what is happening is a result of an error that occurred may prevent this psychological distress from impacting negatively on the patient's condition. Informing the patient about the mistake and letting him or her know about the necessary steps taken to reduce the harm and prevent further occurrence of such errors [17].

The justice ethical principle ensures that patients are treated equitably, and the benefits and burdens of treatments are fairly distributed and communicated. Patients should get what they are owed or what they deserve. The principle of justice therefore dictates disclosure of an error in order to ensure compensation to patients. Patients may be owed compensation for increased health care costs or lost wages in addition to an apology, which nearly all patients demand as the minimum. More specifically, healthcare professionals have an ethical obligation to ensure that the distribution of medical resources to patients would not lead to unanticipated medical errors [18]. 
There are numerous challenges while disclosing medical errors. Medical errors are not usually the fault of a single person delivering health care but due to a flawed system [19]. Changing systems is more complex than punishing a person who makes an error. Fixing flaws in the system is the only way to prevent the same errors from happening over and over again.

Medical institutions have been slow to change their systems because doing so requires at least three things:

1. Admitting that errors are made

2. Communicating the errors to patients and families, throughout the institution and, often, to the media

3. Suffering the uncertain consequences of an error's disclosure, which are commonly thought to include malpractice lawsuits.

There needs to be a culture where individuals do not feel penalized for reporting errors [20]. Moral courage is needed if doctors are to do the right thing when medical errors occur. This moral courage can be facilitated by institutions having policies and guidelines on disclosure of errors in place, training doctors and other hospital staff on how to disclose medical errors and providing emotional support for doctors who make mistakes in their efforts to treat patients and save lives [20].

\section{CONCLUSION}

From the case study it can be concluded that medical students will face the ethical dilemma of medical error disclosure during their training and in clinical practice. Because of no training during the undergraduate curriculum, students face distressing challenges when faced with medical error disclosure which compels them to conceal errors. This further affects the doctorpatient relationship and the healthcare system.

Therefore formal teaching of medical error disclosure in a transparent way during the undergraduate medical training is greatly needed. Ongoing teaching of medical students on importance of disclosure and developing communication skills will help prepare the students in handling medical error disclosure.

\section{REFERENCES}

1. Kohn L. To err is human. 1st edition . Washington, DC: National Academy Press; 2009.

2. Crossing the quality chasm. 1st ed. Washington, D.C.: National Academy Press; 2001.

3. Krizek TJ. Surgical error: ethical issues of adverse events. Arch Surg 2000;135:1359-66.

4. Gallagher T, Bell S, Smith K, Mello M, McDonald T. Disclosing Harmful Medical Errors to Patients. Chest 2009;136(3):897-903.

5. Zulekha SL. A Medical Error: To Disclose or Not to Disclose. J Clin Res Bioethics 2014;5(2):174-8.

6. Anwer L, Abu-Zaid A. Transparency in medical error disclosure: the need for formal teaching in undergraduate medical education curriculum. Med Educn Online 2014;19(1):23542.

7. Wu A, Cavanaugh T, McPhee S, Lo B, Micco G. To tell the truth. J Gen Intern Med 1997;12(12):770-5.

8. Mazor K, Simon S, Gurwitz J. Communicating with patients about medical errors. Arch Intern Med 2004;164(15):1690-5.

9. White A, Bell S, Krauss M, Garbutt J, Dunagan W, Fraser V. How trainees would disclose medical errors: educational implications for training programmes. Med Educ 2011;45(4):372-80.

10. Martinez W, Hickson GB, Miller BM, Doukas DJ, Buckley JD, Song J. Role -modeling and medical error disclosure: a national survey of trainees. Acad Med 2014;89(3):482-9.

11. Medical Error: A Case Based Approach to Apology and Disclosure Video - Brigham and Women's Hospital [Internet]. YouTube. 2017 [cited 15 May 2017].

12. Petronio S. Disclosing Medical Mistakes: A Communication Management Plan for Physicians. The Permanente Journal 2013;17(2):73-9.

13. Robbennolt J. Apologies and Medical Error. Clin Orthopaed Rel Res 2008;467(2):376-82.

14. Gallagher T, Garbutt J, Waterman A, Flum D, Larson E, Waterman B. Choosing Your Words 
Carefully. Arch Intern Med 2006;166(15):1585-9.

15. Crigger N. Always Having to Say You're Sorry: an Ethical Response to Making Mistakes in Professional Practice. Nurs Ethics 2004;11(6):568-76.

16. Beauchamp TL, Childress JF. Principles of Biomedical Ethics. (5thedn), Oxford, New York, USA ; 2001.

17. Fein S, Hilborne L, Spiritus E, Seymann G, Keenan C, Shojania K. The Many Faces of Error Disclosure: A Common Set of Elements and a Definition. J Gen Intern Med 2007;22(6):755-61.

18. Bonney W. Medical errors: Moral and ethical considerations. J Hosp Admin 2013;3(2):80-8.

19. Available from:

http://www.ihi.org/resources/Documents/Shapiro_DisclosingMedicalErrors2008.doc.

20. Fein S, Hilborne L, Kagawa-Singer M, Spiritus E, Keenan C, Seymann G, Sojania K, Wenger N. A Conceptual Model for Disclosure of Medical Errors. In: Henriksen K, Battles JB, Marks ES, Lewin DI, editors. Advances in Patient Safety: From Research to Implementation (Volume 2: Concepts and Methodology). Rockville: Agency for Healthcare Research and Quality (US); 2005.

\author{
************************************ \\ Acknowledgements - Nil \\ Source of Funding - Nil; Conflict of Interest - Nil
}

